\title{
Nexus between Tourism and Gross Domestic Product in Sri Lanka
}

\author{
A.L. Mohamed Aslam \\ Sri Lanka Planning Service \\ Ministry of National Policy Planning \\ Sri Lanka \\ Email: mohamedaslamalm@gmail.com
}

\begin{abstract}
Keywords: Tourism Earning, Gross Domestic Product, Policy Makers, Economies and Sri Lanka
\end{abstract}
\begin{abstract}
Nowadays, policy makers believe that the tourism is a positive tool for economic growth of nations because which helps to economies of countries by several ways. In Sri Lankan experience it was not statistically confirmed. The aim of this study was to test the nexus between the tourism earnings and the gross domestic product in Sri Lanka. To test this nexus this study used time series data during the period of 1970 to 2014, and employed the multiple regressions model. In this study, the gross domestic product in constant price was used as dependant variable and exchange rate, foreign remittance, tourism earning, and inflation rate were considered as independent variables. Based on the regression outcomes, this study found that the tourism positively maintained the nexus on the gross domestic product in Sri Lanka at five percent significant level.
\end{abstract}

\section{Introduction}

Development economists very recently explored the tourism as an income factor of developing countries. In Asian region Sri Lanka has beautiful attraction places from historical period, by this reason this country is called the Garden of god. After independence, the government of Sri Lanka decided to promote the tourism industry for earning the foreign exchanges. Based on this thought, the government established a tourist bureau in 1966. After 1966 the tourism industry expended rapidly. From 1976 to 1982, the tourists arrivals annually increased by 24\%. But the civil war in Sri Lanka badly affected on tourists arrivals. In the recent years, it was recorded that the tourism industry plays an important role in the Sri Lankan economy which has been identified as a tool of rural and national development by the policy makers [6].

The tourism is major source for earning the foreign exchange in developing countries which reduces the unemployment issues and rural poverty in those countries. Therefore, it has been promoted by the rulers of developing countries. In Sri Lanka the tourism is recommended as a tool of rural development. According to the statistics of Sri Lanka Tourism Development Authority (SLTDA), foreign tourists in Sri Lanka arrived 192592 in 1978 which increased as 1005605 in 2012. But it is predicted that the tourists will be increased 2.5 million in end of 2016. By the tourism sector, Sri Lanka earned Rs.18863.3 million in 2001 which increased as 91929 million. But it is expected as Rs. 2.75 billion in 2016. Meanwhile the tourism in Sri Lanka created 57786 direct employments in 2011 which increased as $22 \%$ in2014. In the meantime, the tourism contributed $3 \%$ to gross domestic product of Sri Lanka in 2012 which was increased 5.8\% in 2014. In export of Sri Lanka, the tourism was $7.9 \%$ in 1995 which increased as $16.6 \%$ in 2014 . Likewise, the expenditure of tourism in total imports was $4.66 \%$ in 1995 which extended as $8.3 \%$ in 2014 .

The tourism maintains a narrow nexus on gross domestic product in Sri Lanka which was not systematically studied because in Sri Lanka numbers of studies regarding the nexus between the tourism and gross domestic product are there but none of them clearly defined the nexus between the tourism on gross domestic product. In the meantime, all of them used run out data for analyzing their studies. In this movement, this study is currently essential for exploring the nexus between the tourism and the gross domestic product in Sri Lanka. Therefore, this study attains the nexus through the econometric technique. For this purpose this study designs as introduction, objective, recap of previous studies, research methods, results and discussion, and conclusion. 


\section{Objective}

The objective of this study is to test the nexus between the tourism earning and the gross domestic product in Sri Lanka during the period of 1970 to 2014.

\section{Recap of previous studies}

The nexus between tourism earning and the gross domestic product is well documented in national and international contexts. In this study some selected research articles from them are considered as literatures.

Domestically, [22] tested the significance of tourism on Sri Lankan economy using the time series data from the period of 1970 to 2008. To test this significance this study applied the multiple regressions model. This study found that the tourism significantly impacted on Sri Lankan economy during the sample periods. In the meantime [21] studied the role of tourism in economic growth of Sri Lanka using the annual time series data from 1967 to 2011. This study used tri- variate econometric model and also the Johansen cointegration technique. This study found that the tourism positively impacted on the economic growth of Sri Lanka and also both variables were cointegrated at first difference level during the study periods.

While, [19] investigated the time series behavior of burgeoning international tourist arrival in Sri Lanka: the post war experience using monthly time series data from July 2009 to June 2013.In this study, to test this behavior the classical time series decomposition approach was used. Finally, this study explored that the international tourist arrivals were highly recorded in the month of June and July in Sri Lanka. In the meantime [5] studied the relationship between the tourism and sustainable economic growth during the period of 1978 to 2011. In this study the time series econometric techniques: Engel - Granger cointegration technique, Granger causality test were considered to test this relationship. This study explored that the tourism passively impacted on the economic growth of Sri Lanka and both of them cointegrated at first difference level. Moreover these variables had unidirectional causality among them. While [10] studied the causal relationship between the tourism and economic growth of Sri Lanka using the annul time series data during the period of 1960 to 2000. In this study the variance decomposition analysis used to test the causal relationship between the variables. This study found that the tourism led to economic growth of Sri Lanka.

Meanwhile [13] investigated the relationship between tourism and economic growth in Sri Lanka using the annual time series data from the period of 1977 to 2012. In this study the Granger causality testing approach was employed to test the causality between the variables. This study explored that there was unidirectional causality between the variables. Meanwhile internationally, [8] studied the relationship between the tourism and economic growth of Latin American countries. To test this relationship this study used the conventional classical growth model using the annual time series data the period of 1995 to 2007 . The study found that the tourism industry positively maintained the relationship with the economic growth of Latin America countries. Same authors [9] examined the impact of tourism on economic growth and development in Africa. In this study, the penal data of forty - two African countries were used to test this impact. Finally, this study explored that the tourism supported to uplift the economic growth of African countries and also it was significantly impacted on the economic growth of African countries.

In the meantime, based on Jordanian experience [18] investigated the relationship between the tourism and economic growth using the annual time series data from 1970 to 2009 . This study found that the tourism had maintained positive relationship on economic growth of Jordan in the long run period. This result was gotten from multiple regressions model. In Nepal, a study was conducted by [12] using time series data. This study conducted to test the cointegration relationship between tourism and economic growth. To test this relationship, the Engel - Granger cointegration technique was used. At last, this study concluded that the tourism had short, long - run relationship with the economic growth of Nepal during the sample period.

While, [3] studied the causality relationship between tourism development and economic growth of selected developing countries. In this study, the P-VAR approach was used to test this causality 
using the time series data from 1995 to 2009 . It concluded that the tourism positively maintained the causal relationship on the economic growth of selected countries. In the meantime [1] investigated the relationship between tourism and GDP in the Islamic republic of Iran. In this study, to test the relationship the Johansen - Juseliusco cointegration technique and the Granger causality test were used using the annual time series data during the period of 1968 to 2007. This study explored that the tourism on economic growth of Iran positively maintained the long - run relationship and identified the bidirectional causality relationship each other.

Moreover, [17] studied the relationship between tourism and economic growth of Iran using the annual time series data from the period of 1980 to 2009. To test this relationship, this study used the Johansen - Juseliusco cointegration and VECM techniques. This study found that the tourism and the economic growth of Iran had cointegrated in the long and short - term period. While, [11] analyzed the impact of international tourism on the economic growth of Turkey using the quarterly data from 1985:Q1 to 2008:Q3. In this study the ARDL approach was employed to test the impact of tourism. Finally, this study concluded that the tourism had long run relationship on the economic growth of Turkey. In Pakistan experience a study was conducted by [23] to test short - run relationship between the tourism and the economic development using the annual time series data from the period of 1960 to 2005 . To test this relationship, this study used the Error Correction Model. In conclusion, this study explored that the tourism maintained the short - run relationship on the economic growth of Pakistan during the study period.

In the meantime [16] studied the relationship between tourism and economic growth in Nepal using the time series data from the period of 1974 to 2012. To test this relationship this study used the cointegration error correction model. Based on this technique this study found that the tourism positively preserved the long relationship on the economic growth of Nepal during the study period but it had not maintained the short run relationship. Meanwhile [16] discovered the impact of tourism on economic growth of Pakistan using annual data from 1981 to 2013. In this study to test this impact the simple regression model, ANOVA testing and correlation matrix were employed. Finally this study found that the tourism during the study period positively and significantly impacted on the economic growth of Pakistan and it contributed $0.24 \%$ to gross domestic product.

Even as, [14] studied the relationship between tourism and economic growth of Latin American countries using the time series panel data approach for the period of 1985 to 1998. In this study the tourism in these countries significantly and positively impact on economic growth of Latin American countries. While, [24] studied the relationship between the tourism development and economic growth in Iran using ARDL bound testing approach during the period of 1975 to 2011. In this study the real gross domestic product in Iran was considered as dependent variable and capital formation, international tourist arrivals, international trade, energy consumption and real effective exchange rated were used as independent variables. Moreover the Johansen's cointegration technique was used to test the long run relationship between the variables. This study confirmed that the tourism had significantly and positively impacted on the economic growth of Iran.

Meanwhile, [4] explored the impact of tourism, foreign direct investment and export on economic growth of Pakistan, India, China and Russia using the annual time series data during the period of 1995 to 2008. In this study, to test this impact this study considered the panel ordinary least squares estimation technique using the Cobb - Douglas production function. This study explored that the tourism positively impacted on the economic growth of four selected countries. In the meantime, [5] investigated the relationship between the tourism and economic growth for the south Tyrolean economy. In this study the annual time series data from 1980 to 2006 were considered. Meanwhile, to test the cointegration between the variables, the Johansen method was employed and to test the Granger causality relationship among the variables Granger causality method was used. This study found that the tourism maintained the long run relationship on the economic growth of Tyrolean countries. As [20] studied the relationship between the tourism and economic growth in African countries, to test this relationship this study used the annual time series during the period of 1990 to 2011. Moreover the cointegration technique was also employed. Finally this study found that the tourism had long run relationship with the economic growth of African countries during the study periods. 
All literatures in this study used several techniques to get the results, but any of them did not illustrate like using the technique of this study. Therefore this study considers the following research methods and analytical techniques.

\section{Research Methods}

In research method, this study considers and discusses the very essential research steps for testing the nexus between the tourism earning and gross domestic product in Sri Lanka.

\section{Variables and data}

In this study, the gross domestic product in constant price was considered as dependent variables and tourism earning, foreign exchange rate, foreign remittance and inflation rate were employed as independent variables. The earnings tourism was key independent variable and others were controlled variables. In the meantime, to achieve the objective of this study the annual time series date from the period of 1970 to 2014 were considered which were assembled from the annual reports of Central Bank of Sri Lanka.

\section{Analytical techniques:}

In this study, four types of multiple regressions models: linear, log- linear, linear - log and double log models were tested using empirical time series data for choosing the suitable regressions model and to explain the outcome of the estimated regressions. To choose the suitable model, the Rsquared values, F- values, and Durbin Watson statistics, CUSUM plot of whole models were compared among them. The Breusch - Godfrey LM test was employed to test the autocorrelation affects of the whole models. To explain the overall contribution of the tourism earnings in Sri Lanka, the probability value of the tourism variable and its $t$ - statistics in the selected model were considered.

\section{Model specification:}

In this study, the relationship between the dependent and independent variables were revealed the following mathematical function.

$$
G D P_{t}=f\left(E R_{t}, F R_{t}, T E_{t}, I N F_{t}\right)
$$

From the function (1), the following models were derived:

Linear model: $G D P_{t}=\beta_{0}+\beta_{1} E R_{t}+\beta_{2} F R_{t}+\beta_{3} T E_{t}+\beta_{4} I N F_{t}+\varepsilon_{t}$

Log- linear model: $\operatorname{lnGDP_{t}}=\beta_{0}+\beta_{1} E R_{t}+\beta_{2} F R_{t}+\beta_{3} T E_{t}+\beta_{4} I N F_{t}+\varepsilon_{t}$

Linear- log: GDP $=\beta_{0}+\beta_{1} \ln E R_{t}+\beta_{2} \ln F R_{t}+\beta_{3} \ln T E_{t}+\beta_{4} \ln I N F_{t}+\varepsilon_{t}$

Double log: $\ln G D P_{t}=\beta_{0}+\beta_{1} \ln E R_{t}+\beta_{2} \ln F R_{t}+\beta_{3} \ln T E_{t}+\beta_{4} \ln I N F_{t}+\varepsilon_{t}$

\section{Where:}

$G D P_{t}$ : Gross Domestic Product; $E R_{t}$ : Foreign Exchange Rate; $F R_{t}$ : Foreign Remittance; $T E_{t}$ : Tourism Earning; $I N F_{t}$ : Inflation rate; $\varepsilon_{t}$ : Error terms; $\beta_{i}$ : Coefficients of the model

\section{Results and Discussion}

As mentioned in model specification, four types of models are fitted to interpret the nexus between the tourism earnings and gross domestic product in Sri Lanka. The following table shows the basic information of fitted models. 
Table 1: Basic Information for Considered Models

\begin{tabular}{|c|c|c|c|}
\hline Models & R-squared & F-statistic & Durbin Watson value \\
\hline Linear model & 0.979 & 369.6046 & 2.258083 \\
\hline Linear - log model & 0.957 & 18.467 & 1.296672 \\
\hline Log- linear model & -5.834 & 5.6700 & 0.252108 \\
\hline Double log model & 0.997 & 2935.478 & 1.456857 \\
\hline
\end{tabular}

Source: Calculated from secondary data

In the table -1 , it shows the basic features of the fitted regression models, from these models the double log model is selected to interpret the nexus between tourism earnings and the gross domestic product in Sri Lanka. Because, the R-squared and F- statistic of this model are higher than other models.

In econometric view, to test the validity of models the CUSUM plot is employed. Therefore, this study also considers the CUSUM plot approach to test the validity of whole models. The following figures show the CUSUM plots of whole models separately.

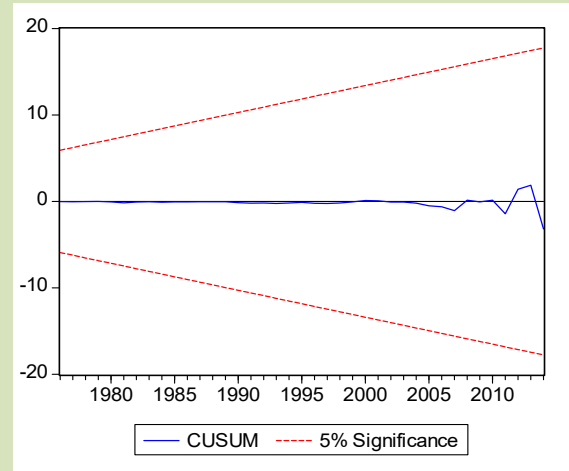

(A): Linear regression model

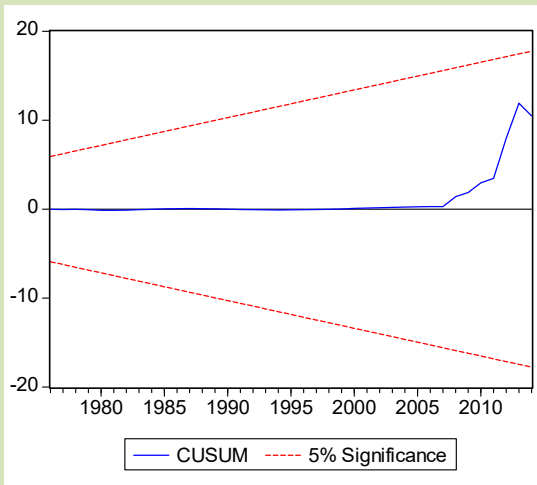

(C): Log regression model

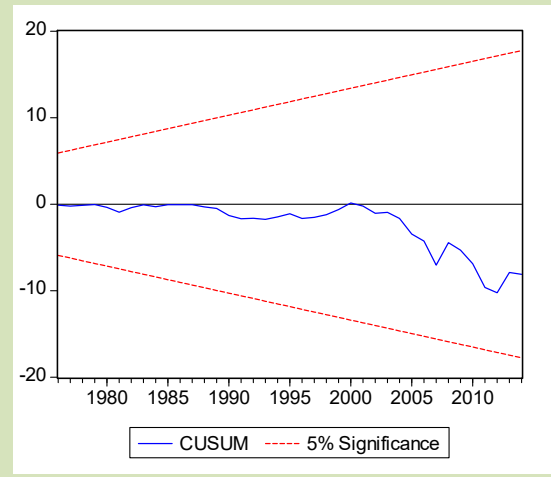

(B): Linear regression model

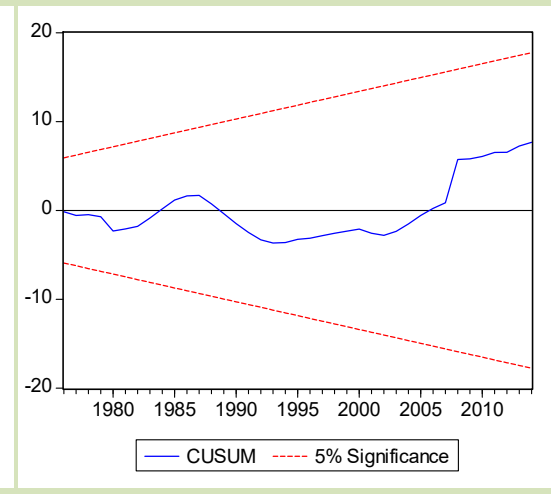

(D): Double log regression model

\section{Figures 1: CUSUM plots for fitted models}

As shown in the figures, whole models in this study are validity because CUSUM plot lines of whole models are situated between the grids line at 5\% significant level. Therefore, all models in this study are strong. But the CUSUM line of double log model (D) is sequentially waving between the grid lines. Therefore, this model is very suitable when compared with other models. Therefore, it is selected to interpret the nexus between the variables.

Next, to test the serial correlation effect of models in this study, the Breusch - Godfrey serial correlation LM test is employed. The following table illustrates the results of Breusch - Godfrey serial correlation LM test of models. 
Table 2: Serial Correlation Results of Models

\begin{tabular}{|l|l|l|l|l|}
\hline Models & F- statistic & p- value & R-squared & p-value \\
\hline Linear & 9.068660 & 0.000624 & 14.80267 & 0.000610 \\
\hline Log- Linear & 5.174662 & 0.010433 & 9.835823 & 0.007314 \\
\hline Linear- Log & 7.871473 & 0.001418 & 13.43180 & 0.001211 \\
\hline Double Log & 1.513962 & 0.233354 & 3.404039 & 0.182315 \\
\hline
\end{tabular}

Source: Calculated from secondary data during the sample period

In the table -2 , the probability value of the double log model is $18 \%$ which is greater than at $5 \%$ significant level. But probability values of other models are less than at 5\% significant level. Therefore, the double $\log$ model is not suffering from the serial correlation. So this study recommends the double log model to interpret the regression outcomes. Therefore, the following table shows the regression outcomes of double log model.

Table 3: Regression Outcome of Fitted Model

\begin{tabular}{|c|c|c|c|c|}
\hline \multicolumn{5}{|c|}{$\ln G D P_{t}=8.67-0.688 \ln E R_{t}+0.716 \ln F R_{t}+0.089 \ln T E_{t}-1.006 \ln I N F_{t}$} \\
\hline Variables & Coefficient & Std. Error & t- statistic & P-value \\
\hline $\mathrm{C}$ & 8.667040 & 0.1932742 & 44.84385 & $0.0000 *$ \\
\hline $\ln E R_{t}$ & -0.688382 & 0.117230 & -5.872044 & $0.0000^{*}$ \\
\hline $\ln F R_{t}$ & 0.719683 & 0.042648 & 16.87500 & $0.0000 *$ \\
\hline $\ln T E_{t}$ & 0.088964 & 0.037127 & 2.396204 & $0.0213 * *$ \\
\hline $\operatorname{lnINF_{t}}$ & -1.006490 & 0.024478 & -41.11845 & $0.0000 *$ \\
\hline \multicolumn{2}{|c|}{ R-squared: 0.997350} & D.W: 1.456857 & \multicolumn{2}{|c|}{ F-statistic: 2935.4} \\
\hline
\end{tabular}

Source: Calculated from secondary data during the sample period

* 1\%: significant level ** 5\%: significant level

Based on the table -3 , it has four explanatory variables: exchange rate, foreign remittance, tourism earning, and inflation rate.

Here, the main independent variable in this regression model is tourism earning which has positively and significantly maintains the nexus on the gross domestic product in Sri Lanka. In the regression model, the coefficient of this variable is 0.089 and its probability value is less than five percent which points out that if the tourism earning increases by one percent, the gross domestic product will be increased by 0.089 . In the meantime, if the tourism earning decreases by one percent the gross domestic product will be decreased by 0.64 percents.

The exchange rate in this regression model has negative relationship on the gross domestic product. The coefficient of this variable is (-0.688) and its probability value is less than one percent which indicates that if the exchange rate increases by one percent, the gross domestic product will be decreased by 0.688 percent. On the other hand, if the exchange rate decreases by one percent the gross domestic product will be increased by 0.688 percents.

Moreover, the foreign remittance in this model positively and significantly maintains the relationship on the gross domestic product. The coefficient of this variable in the estimated model is 0.71 which delivers that if the foreign remittance increases by one percent the gross domestic product will be increased by 0.71 . Otherwise, if the foreign remittance decreases by one percent the gross domestic product will be decreased by 0.71 .

In the table - 3, the inflation rate in this estimated model maintains the inverse relationship on the gross domestic product in Sri Lanka at one percent significant level. The coefficient of this variable is (-1.006) which means that if the inflation increases by one percent, the gross domestic product will be decreased by 1.006 percent. On the other hand, if the inflation decreases by one percent, the gross domestic product will be increased by1.006 percent. 


\section{Conclusion}

In this study, to investigate the nexus between tourism earning and gross domestic product in Sri Lanka, this study used the following variables: tourism earning, exchange rate, foreign remittance, inflation rate, and the gross domestic product. Here, the gross domestic product was as depend variable and others were used as independent variables. And also, the multiple regressions model was employed. Based on the outcomes of regression, this study found that the tourism positively maintained the nexus on the gross domestic product in Sri Lanka at five percent significant level during the sample period. Therefore, this study suggests that the tourism policy makers must formulate the tourism friendly policies in Sri Lanka.

\section{References}

[1]. A. Assadzadeh, M.H.N. Nasab, Investigating the relationship between Tourism Industry and GDP in the Islamic Republic of Iran", International Review of Business Research Papers, 8:2 (2012) 85-95

[2]. A.J. Samimi, S. Sadeghi, Tourism and Economic Growth in Developing Countries: P- VAR Approach, Middle - East Journal of Scientific Research, 10:1 (2011) 28-32

[3]. A.J. Samimi, S. Sadeghi, S. Sadeghi, Tourism and Economic Growth in Developing Countries: P- VAR Approach", Middle - East Journal of Scientific Research, 10:1(2011) 28-32

[4]. A.K. Tiwari, Tourism, Export and FDI as a Means of Growth: Evidence from four Asian Countries, The Romanian Economic Journal, XIV:40 (2011) 131- 151

[5]. A.M. Mustafa, S. Santhirasekaram, Empirical Investigation of the relationship between toruism receipts and sustainable economic growth in Sri Lanka, Journal of Emerging Trends in Economics and Management Sciences, 5:7 (2014) 131- 137

[6]. A.M.P. Adikari, The Study of Impacts of Tourism Industry on Employment and Gross Domestic Product in Sri Lanka, Proceeding of First Annual Research Conference, Rajarata University of Sri Lanka (2013)

[7]. A.R Aleemi, M.A. Qureshi, (2015), Tourism receipts and Economic Growth: Empirical Evidence from Pakistan, International Journal of Research, 2:2 (2015) 1401-1409

[8]. B. Fayissa, C. Nisah, C. Tadesse, Tourism and Economic Growth in Latin American Countries (LAC): Further Empirical Evidence, Department of Economics and Finance Working Paper Series (2009)

[9]. B. Fayissa, C. Nsiah, B. Tadasse, The Economics of the impact of tourism on economic growth and development in Africa, Middle Tennessee State University, Department of Economics and Finance. Working Paper Series, August (2007)

[10]. B.G. Wickremasinghe, R. Ihalanayaka, The causal relationship between tourism and economic growth in Sri Lanka: some empirical evidence", (2007) available on:

http://search.informit.com.au/documentsummary;dn=532419502345827: res= IELBUS, 742753

[11]. B. Savas, A. Beskaya, F. Samiloglu, Analyzing The Impact of International Tourism on Economic Growth in Turkey", Journal of Social Sciences, 6:12 (2010) 121- 136

[12]. B.P. Gautam, Tourism and Economic Growth in Nepal, Nepal Rastra Bank Economic Review, Nepal (2009) 19-30

[13]. J. Suresh, S. Senthilnathan, Relationship between tourism and Economic Growth in Sri Lanka, (2013) available on: $\mathrm{http}: / /$ ssm.com/abstract=2373931 
[14]. J.L. Eugenio- Martin, N.M. Morales, R. Scarpa, Tourism and Economic Growth in Latin American Countries: A Panel Data Approach, Fondazione Eni Enrico Mattei Working Paper Series, NOTA DI LAVORO (2004)

[15]. J.G.Brida, N.A. Risso, The tourism as determinant of the economic growth in South Tyrol, (2009) Retrieved available on: www.com/abstract.

[16]. K. Dhungel, An Econometric Analysis on the Relationship between Tourism and Economic Growth: Empirical Evidence from Nepal, International Journal of Econometrics and Financial Management 3:2 (2015) 84- 90

[17]. M, Lashkarizadeh, Z. Keshmir, H.P. Gashti, R.B. Shahrivar, Eveluation of the Relationship between Tourism Industry and Economic Growth in Iran”, Asian Journal of Business and Management Sciences, 1:9 (2010) 88-97

[18]. M. Kirishan, Time - Series Evidence for Tourism - led Growth Hypothesis: A case study of Jhordan", International Management Review 46:4 (2011) 985-995

[19]. N. Kurukulasooriya, E.I. Lelwala, Short - Term Forecasting of International Tourist Arrivals to Sri Lanka: Comparative Evidence Using Exponential Smoothers. The $6^{\text {th }}$ International Research Conference on Management and Finance Colombo: Faculty of Management, University of Colombo (2011)

[20]. O.I. Kareem, A reassessment of Tourism - Exports Let Growth Hypothesis in Africa, American Journal of Tourism Research, 2:1 (2013) 130- 140

[21]. P.M.B Jayathilaka, Tourism and Economic Growth in Sri Lanka: Evidence From Cointegration and Causality Analysis, International Journal of Business, Economics and Law, $2: 2(2013) 22-27$

[22]. R. Ranasinghe, R. Deyshappriya, Analyzing the Significance of Tourism on Sri Lankan economy, (2012) available on www.kln.ac.lk/fcms/ICBI2012/image/ ICBM/dccs/TRM001.pdf

[23]. S. Khalil, M.K. Kakar, Waliullah, Role of Tourism in Economic Growth: Empirical Evidence from Pakistan Economy", The Pakistan Development Review 46:4 (2007) 985- 995

[24]. S.K. Yazdi, N. Mastorakis, Tourism Development and Economic Growth in Iran: Using ARDL Bound tests, Advance in Economics, Law and Political Sciences, (2012) 172-180 